\title{
ANALISIS POTENSI DAN PENGELOLAAN PERIKANAN DALAM PERSPEKTIF KETAHANAN PANGAN DI WILAYAH PESISIR KABUPATEN LAMPUNG BARAT
}

\author{
(Analysis of Fisheries Potential and Management in Food Security Perspective at Coastal Zone \\ of West Lampung Regency) \\ Nazdan ${ }^{1}$, Budi Setiawan ${ }^{2}$, dan Dadang Sukandar ${ }^{2}$ \\ ${ }^{1}$ Program Studi Manaj emen Ketahahan Pangan (MKP), Sekolah Pascasarjana, IPB. \\ 2 Departemen Gizi Masyarakat, Fakultas Ekologi Manusia (FEMA), IPB \\ Tel: 0251-8628304/ 8621258; Fax: 0251-8625846/8622276
}

\begin{abstract}
The aim of this study was to analyze the potential resources and management of fisheries during the periods of 2003-2007 at the coastal zone of West Lampung. Primary and secondary data was analyzed using SWOT. SWOT analysis is a technique used to identify various factors systematically in order to formulate a management strategy. The result showed that the total score for internal factor (strengths-weaknesses) was 0.23 and the total score for external factor was -0.32 (opportunities-threats); which placed the fisheries management at the coastal zone of West Lampung regency in the second quadrant position. The priority of alternative strategy carried out for optimum and sustainable fisheries management was to develop aquaculture (fresh water and estuary), to resolve conflicts of interest on natural resources used at the coastal zone of West Lampung, and to improve the involvement of formal and non formal institutions in implementing environment friendly efforts as well as in resolving environmental degradation problems.
\end{abstract}

Keywords: coastal zone, SWOT, West Lampung

\section{PENDAHULUAN}

Ikan sebagai bahan pangan mempunyai nilai gizi tinggi dengan kandungan protein yang tersusun dalam asam-asam amino esensial yang sangat diperlukan untuk pertumbuhan dan kecerdasan manusia. Ikan mengandung asam lemak tidak jenuh omega-3 yang mengandung manfaat antara lain: merendahkan kadar kolesterol dalam darah, meningkatkan kemampuan belajar dan mengingat, meningkatkan kekebalan tubuh, menurunkan angka kematian akibat penyakit jantung dan mencegah naiknya tekanan darah (Karyadi dkk., 1993). Mengingat peran penting bahan pangan ikan tersebut bagi kualitas sumber daya manusia di Kabupaten Lampung Barat maka diperlukan ketersediaan ikan yang cukup untuk dikonsumsi oleh seluruh penduduk. Oleh karena itu untuk meningkatkan ketersediaan ikan perlu disusun strategi pengelolaan perikanan yang memperhatikan keseimbangan aspek lingkungan, ekonomi dan sosial agar dapat terhindar dari kegagalan di tingkat pelaksanaannya sehingga pengusahaannya diharapkan dapat berkelanjutan.

Kabupaten Lampung Barat merupakan daerah yang memiliki wilayah pesisir cukup lu- as di Propinsi Lampung yang didalamnya terdapat Sumber Daya Ikan (SDI) yang besar. Wilayah ini memiliki garis pantai sepanjang 221.5 $\mathrm{km}$ dengan potensi perikanan tangkap dan perikanan budidaya yang cukup potensial. Berdasarkan undang-undang otonomi daerah, kabupaten ini memiliki wilayah laut seluas \pm 409 $\mathrm{km}^{2}$. Potensi SDI pesisir ini diharapkan memberikan manfaat dan dampak positif bagi perekonomian dan ketahanan pangan masyarakat setempat. Dahuri (2008) menyebutkan bahwa sektor kelautan dan perikanan pada masa mendatang akan menjadi penggerak utama (prime mover) ekonomi karena besarnya potensi yang dimiliki.

Perikanan di wilayah pesisir Kabupaten Lampung Barat relatif belum berkembang, khususnya perikanan budidaya yang meliputi budidaya air tawar, air payau, serta budidaya air laut. Sedangkan perikanan tangkap telah lama dilakukan oleh masyarakat pesisir, walaupun dalam usahanya tersebut masih menggunakan teknologi, armada dan alat tangkap tradisional. Kegiatan pasca panen dan pengoIahan hasil perikanan telah dilakukan seiring dengan adanya produksi ikan, tetapi sampai saat ini masih dalam skala kecil (rumah tangga) dengan tujuan mencegah pembusukan 
(kerusakan), meningkatkan nilai tambah, untuk mengantisipasi saat kelebihan produksi di musim ikan, serta sebagai bentuk memanfaatkan hasil tangkap sampingan (by catch).

Potensi perikanan yang ada di wilayah pesisir seharusnya dikelola secara baik dengan memperhatikan aspek ekonomi, lingkungan dan sosial sehingga dapat dimanfaatkan secara berkelanjutan. Eksploitasi perikanan tangkap yang tidak ramah lingkungan (illegal fishing) dan pengembangan tambak yang berakibat destruktif harus diantisipasi agar kerusakan seperti yang terjadi di berbagai daerah di Indonesia tidak terjadi atau paling tidak dapat dikurangi di Kabupaten Lampung Barat.

Dengan berlakunya Undang-undang (UU) No. 6 tahun 1991 tentang Pembentukan Kabupaten Lampung Barat dan Undang-Undang Nomor 32 tahun 2004 tentang Pemerintahan Daerah telah memberikan keleluasaan bagi pemerintah daerah Kabupaten Lampung Barat dalam mengelola sumberdaya perikanan (SDP) yang dimiliki, termasuk pengelolaan SDP di wilayah pesisir. Pemberian otonomi dapat mempersingkat rentang kendali pembangunan, termasuk dalam rangka pengembangan perikanan wilayah pesisir dan laut. Keleluasaan pengelolaan sumber daya pesisir dan laut tersebut diperkirakan akan mendorong semakin intensifnya pemanfaatan SDI dan lingkungannya guna meningkatkan pendapatan daerah, penciptaan lapangan kerja, peningkatan pendapatan masyarakat, peningkatan devisa ekspor daerah serta pembangunan dalam rangka ketahanan pangan di wilayah Kabupaten Lampung Barat pada umumnya.

Pemasalahan yang ditemui berkaitan dengan pengelolaan perikanan di wilayah pesisir Kabupaten Lampung Barat mencakup aspek teknis, kapital, sumberdaya manusia (SDM) dan manajemen. Hal tersebut antara lain tercermin dari: belum dikuasainya teknologi, masih kurangnya modal, rendahnya SDM, indikasi tangkap lebih pada wilayah tepi (batas 2 mil), pasca panen kurang baik, harga ikan yang berfluktuasi yang cenderung merugikan nelayan, konflik penggunaan lahan, alat dan armada penangkapan tidak memadai serta masalah ketersediaan benih ikan dan pakan untuk budi daya (Diskanla, 2006).

Tujuan penelitian ini adalah untuk: 1) Menganalisis potensi sumberdaya perikanan di wilayah pesisir Kabupaten Lampung Barat, 2) Menganalisis pengelolaan perikanan di wilayah pesisir Kabupaten Lampung Barat periode tahun 2003 - 2007, dan 3) Merumuskan rekomendasi strategi dan rencana aksi pengelolaan per- ikanan di wilayah pesisir Kabupaten Lampung Barat dalam perspektif ketahanan pangan. Hasil penelitian ini diharapkan bermanfaat dalam memberikan masukan dan informasi bagi perencana dan pengambil keputusan dalam rangka pengelolaan perikanan wilayah pesisir Kabupaten Lampung Barat, serta diharapkan pula dapat menjadi salah satu referensi dalam kajian pengelolaan perikanan dan pengembangan keilmuan yang terkait dengan ketahanan pangan.

\section{METODE PENELITIAN}

\section{Desain dan Tempat Penelitian}

Pendekatan dalam penelitian ini menggunakan metode deskriptif. Dan dilakukan di Wilayah pesisir Kabupaten Lampung Barat yang meliputi 8 (delapan) kecamatan pesisir. Pemilihan lokasi dilakukan secara sengaja (purposive) dengan alasan: (1) Wilayah pesisir merupakan basis perikanan tangkap dan penyumbang produksi perikanan terbesar di Kabupaten Lampung Barat. (2) Wilayah pesisir memiliki banyak potensi Sumber Daya Perikanan (SDP) non penangkapan yang belum dimanfaatkan.

\section{Цenis dan Cara Pengumpulan Data}

Data yang dikumpulkan berupa data primer dan sekunder. Data primer diperoleh dengan observasi dan wawancara dengan pelaku usaha di bidang perikanan, dan data sekunder diperoleh dari pihak terkait berupa laporan, hasil penelitian, peraturan, dan dokumen yang menunjang (Tabel 1).

\section{Analisis Pengelolaan Perikanan di Wilayah Pesisir}

Analisis pengelolaan perikanan di wilayah Kabupaten Lampung Barat dilakukan dengan menggunakan Analisis SWOT. Analisis SWOT disebut juga analisis situasi yang digolongkan ke dalam faktor lingkungan internal (kekuatan dan kelemahan) atau sering dikatakan dampak secara langsung dan faktor lingkungan eksternal (peluang dan ancaman) atau sering dikatakan dampak secara tidak langsung. Kedua faktor tersebut memberikan dampak positif yang berasal dari peluang dan kekuatan serta dampak negatif yang berasal dari ancaman dan kelemahan. Matriks SWOT menggambarkan secara jelas bagaimana peluang dan ancaman yang dihadapi dapat disesuaikan dengan kekuatan dan kelemahan yang dimiliki (Tabel 2). Untuk menentukan strategi pengem bangan perikanan di wilayah pesisir Kabupaten Lampung Barat ini dilakukan dengan analisis 
SWOT (Strength, Opportunities, Weakness dan Threats) yaitu dilakukan dengan mengevaluasi dan mengidentifikasi faktor-faktor SWOT yang mempengaruhi pengelolaan perikanan di wilayah pesisir.

Dalam pembuatan analisis SWOT agar keputusan yang diperoleh lebih tepat, maka perlu melalui tahapan-tahapan proses sebagai berikut (Marimin, 2004);

1. Tahap evaluasi faktor eksternal dan internal. Tahap ini digunakan untuk mengidentifikasi faktor-faktor yang menjadi kekuatan, kelemahan, peluang, dan ancaman dengan menganalisis data-data yang relevan dengan lingkup penelitian.

2. Tahapan analisis (analisis SWOT), yaitu pembuatan matriks internal dan matriks eksternal dan matriks SWOT. Bobot (B) setiap unsur faktor internal dan eksternal merupakan kunci keberhasilann pembangunan (Key Success Faktor/ KSF) yang memiliki nilai antara 0 (tidak penting) sampai 1 (sangat penting). Bobot KSF tersebut ditentukan dengan membandingkan derajat kepentingan (urgensi) setiap KSF yang satu dengan KSF yang lain. Faktor-faktor kunci keberhasilan tersebut kemudian diberi peringkat/ rating $(R)$ atau tingkatan yang menandakan nilai dukungan masing-masing faktor dalam pencapaian tujuan, yang dimulai dengan rating 5 (sangat berpengaruh), 3 (berpengaruh), dan 1 (kurang berpengaruh). Bobot faktor dan rating akan menentukan skor (BxR) atau nilai bobot dukungan terhadap pencapaian tujuan pengelolaan perikanan (Tabel 3). Dalam tahap ini peneliti membuat justifikasi sendiri terhadap nilai urgensi (NU) dan rating (R)

Tabel 1. J enis dan Sumber Data

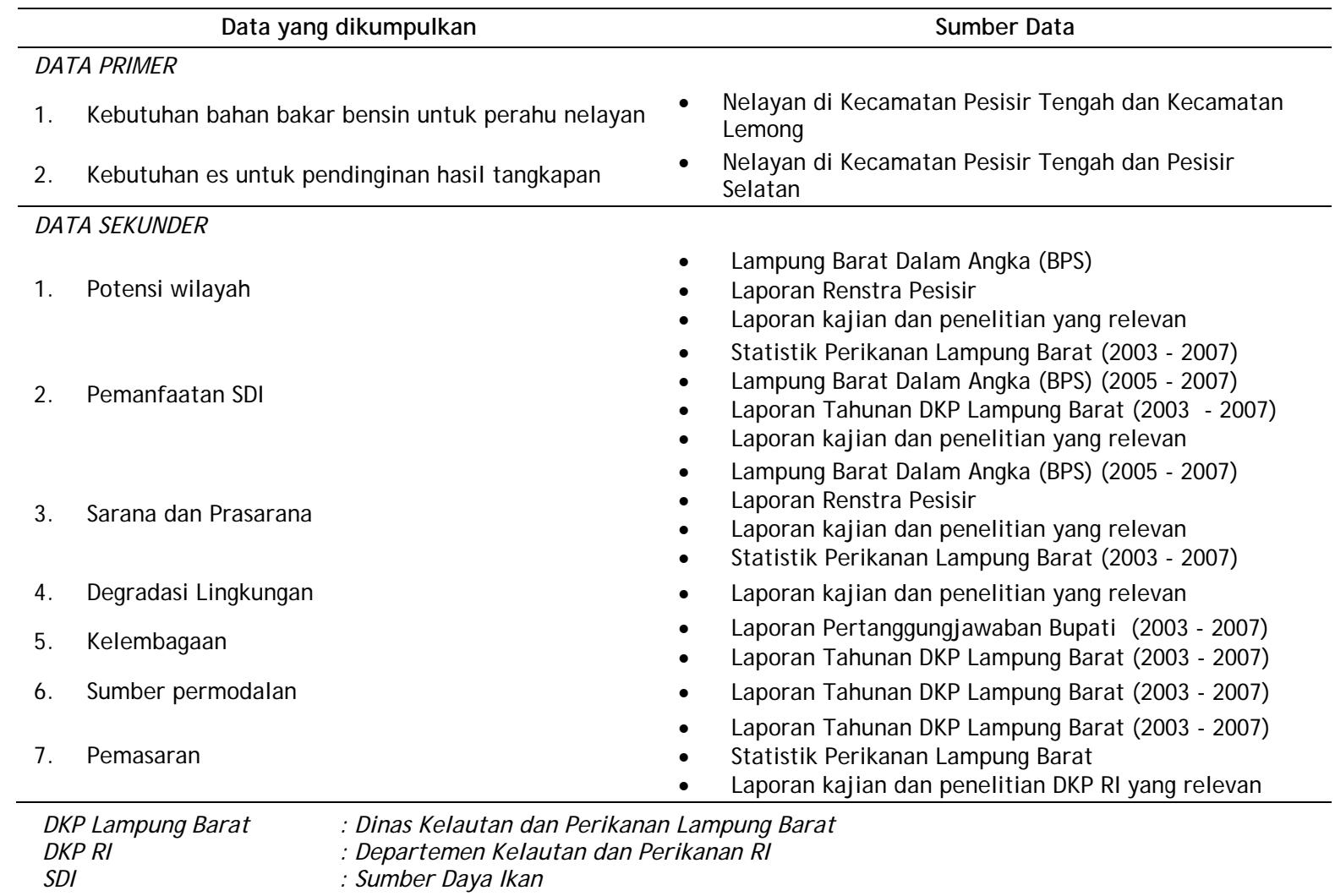

Tabel 2. Matriks Analisis SWOT

\begin{tabular}{lcc}
\hline & Kekuatan (Strength) & Kelemahan (Weaknesses) \\
Eksternal Faktor & & \\
\hline Peluang (Oportunities) & Strategi Kekuatan-Peluang (SO) & Strategi Kelemahan-Peluang (WO) \\
Ancaman (Threats) & Strategi Kekuatan-Ancaman (ST) & Strategi Kelemahan-Ancaman (WT) \\
\hline
\end{tabular}

Rangkuti, 2006 
dari setiap KSF berdasarkan data dan kondisi aktual di lapangan yang berpengaruh terhadap pencapaian pengelolaan perikanan yang optimal dan berkelanjutan.

Selanjutnya dari penghitungan selisih skor dalam setiap faktor SWOT diperoleh total skor faktor internal dan skor faktor eksternal yang digunakan untuk mengetahui posisi strategi pengelolaan perikanan di wilayah pesisir ada pada posisi kuadran tertentu dalam kuadran strategi SWOT.

3. Tahapan pengambilan keputusan (penentuan alternatif strategi). Dalam tahap pengambilan keputusan matrik SWOT ini dilakukan dengan merujuk kembali terhadap KSF yang memiliki bobot yang paling berpengaruh terhadap pencapaian tujuan. Strategi pada matriks hasil SWOT dihasilkan dari penggunaan unsur-unsur kekuatan untuk mendapatkan peluang (SO), penggunaan peluang yang ada untuk menghadapi ancaman (ST), pengurangan kelemahan dengan memanfaatkan peluang yang ada (WO) dan pengurangan kelemahan untuk menghadapi ancaman yang akan datang (WT).

Strategi yang dihasilkan terdiri dari beberapa alternatif strategi yang dibuat difokuskan kepada kuadran posisi pengelolaan terlebih dahulu. Selanjutnya untuk menentukan prioritas strategi dilakukan analisis keterkaitan setiap alternatif strategi dengan 5 unsur penting yang aktual dimiliki pelaksana strategi untuk mewujudkan alternatif strategi yang bersangkutan. Kelima unsur tersebut adalah a) sumber daya manusia, b) metode pelaksanaan, c) sarana dan prasarana, d) anggaran/dana, dan e) organisasi/ kelembagaan. Hubungan keterkaitan antara alternatif strategi dengan setiap unsur penting tersebut di beri nilai sesuai dengan kondisi sebenarnya sebagai berikut: nilai 1 = sangat rendah, 2 = rendah, 3 =cukup tinggi, 4 = tinggi, dan nilai 5 = sangat tinggi. J umlah nilai unsur penting dari setiap alternatif strategi tersebut merupakan skor yang akan menentukan peringkat atau prioritas dari setiap alternatif strategi (Tabel 4).

Namun demikian, strategi masih bersifat normatif, oleh karena itu dalam penelitian ini strategi yang dihasilkan dari analisis SWOT diuraikan dalam bentuk rencana aksi berupa program atau kegiatan sebagai implementasi dari alternatif strategi yang direkomendasikan

\section{HASIL DAN PEMBAHASAN}

\section{Potensi Sumberdaya Pangan}

Berdasarkan hasil analisa potensi perikanan di wilayah pesisir Kabupaten Lampung Barat, diketahui wilayah pesisir ini memiliki Sumber Daya Ikan (SDI) yang cukup besar untuk ditingkatkan pengelolaannya. Wilayah pesisir ini memiliki potensi perikanan tangkap di laut lestari sebesar 15696.56 ton/tahun dengan tingkat pemanfaatan rata-rata $52 \%$ setiap tahunnya. Perikanan budidaya di wilayah pesisir memiliki potensi Iahan 334.5 ha untuk budi daya kolam air tawar dengan tingkat pemanfaatan Iahan $12.43 \%$ dan 6500 ha potensi Iahan budi daya air payau (tambak) yang baru dimanfaatkan sebesar $0.62 \%$ Sementara itu potensi lahan budi daya di perairan umum (sungai dan rawa) sebesar 419 ha hingga kini belum dimanfaatkan. Keragaan produksi perikanan di Kabupaten Lampung Barat pada tahun 2007 adalah 9755.90 ton yang masih didominasi oleh perikanan tangkap sebesar 9116.5 ton, dan dari perikanan budidaya 639.4 ton. Dengan demikian perikanan budidaya hanya memberikan kontribusi yang kecil (6.5\%) dari total produksi perikanan di Kabupaten Lampung Barat. Kontribusi produksi perikanan di wilayah pesisir diketahui mencapai $90.78 \%$ dari total produksi perikanan di Kabupaten Lampung Barat.

Berdasarkan Statistik Perikanan Kabupaten Lampung Barat tahun 2007, diestimasi produksi perikanan (tangkap dan budi daya) dapat memenuhi kebutuhan kon-sumsi protein ikan sebesar $7.66 \mathrm{gr} / \mathrm{kap} / \mathrm{hari}$, atau baru mencapai $85 \%$ dari jumlah protein ikan yang dianjurkan untuk dikonsumsi ( $9 \mathrm{gr} / \mathrm{kap} / \mathrm{hari}$, WNPG 2004). Tingkat konsumsi protein ikan tersebut ternyata lebih rendah $10 \%$ dari tingkat konsumsi protein ikan nasional (8.4 gr/ kap/hari, DKP $\mathrm{RI}$, 2008) walaupun Kabupaten Lampung Barat memiliki potensi sumberdaya ikan di wilayah pesisir yang cukup besar. Hal ini menunjukkan bahwa pengelolaan perikanan di Kabupaten Lampung Barat masih belum optimal sehingga diperlukan strategi yang tepat untuk mengoptimalkan pengelolaan perikanan di wilayah pesisir tersebut dalam perspektif ketahanan pangan.

\section{Analisis pengelolaan perikanan di wilayah pesisir \\ Dari tabel evaluasi faktor internal dan eksternal (Tabel 3) diperoleh hasil penilaian faktor internal dengan mempertimbangkan as- pek kekuatan dan kelemahan serta faktor}


eksternal dengan mempertimbangkan aspek peluang dan ancaman dengan skor sebagai berikut:

1. Skor kekuatan (S) adalah 1.74 sedangkan skor kelemahan (W) adalah 1.51 sehingga bila $\mathrm{S}$ - W yang merupakan sumbu $\mathrm{X}$ adalah 0.23

2. Skor peluang (0) adalah sebesar 1.21 sedangkan skor ancaman ( $\mathrm{T}$ ) adalah 1.53 sehingga bila $\mathrm{O}-\mathrm{T}$ yang merupakan sumbu Y adalah -0.32

Kemudian koodinat sumbu $X(S-W)$ dan sumbu $Y(O-T)$ ditetapkan pada diagram analisis SWOT sehingga dapat diketahui strategi pengelolaan perikanan di wilayah pesisir Kabupaten Lampung Barat (Gambar 1) berada pada kuadran II yang artinya adalah mendukung strategi diversifikasi (Strategi ST), yaitu suatu strategi yang memaksimalkan atau menguta- makan unsur kekuatan untuk mengatasi ancaman yang ada (Gambar 1).

Berdasarkan prioritasnya berturut-turut strategi pada kuadran ke II tersebut dapat ditunjukkan pada Tabel 4 yaitu: Prioritas-1) pengembangan budidaya perikanan air tawar dan payau (ST1), Prioritas-2) Menyelesaikan konflik kepentingan dalam pemanfaatan SDA (ST3) dan, Prioritas-3) meningkatkan peran kelembagaan formal dan non formal dalam menerapkan usaha yang ramah lingkungan dan penanggulangan degradasi lingkungan (ST2). Arahan strategi tersebut di atas masing-masing dapat diimplementasikan melalui program dan kegiatan. Strategi ST1 dapat diimplementasikan melalui progam dan kegiatan; pengembangan budi daya kolam di Kecamatan Karya Penggawa dan Pesisir Tengah, serta mengembangkan budi daya tambak di Kecamatan Bengkunat.

Tabel 3. Matrik evaluasi faktor eksternal dan internal

\begin{tabular}{|c|c|c|c|}
\hline \multirow{2}{*}{ Uraian Faktor Internal dan Eksternal } & \multirow{2}{*}{\begin{tabular}{|c|} 
Bobot \\
$(\%)$
\end{tabular}} & \multirow{2}{*}{$\begin{array}{c}\text { Rating } \\
\text { (R) }\end{array}$} & \multirow{2}{*}{$\begin{array}{c}\text { Skor } \\
\text { (BxR) }\end{array}$} \\
\hline & & & \\
\hline \multicolumn{4}{|l|}{ STRENGTH (S)/ KEKUATAN } \\
\hline 1. Potensi dan keragaman SD Perikanan & 14.29 & 5 & 0.71 \\
\hline 2. Adanya kelembagaan formal yang mendukung & 12.09 & 4 & 0.48 \\
\hline 3. Adanya kelembagaan Informal yang mendukung & 1.10 & 2 & 0.02 \\
\hline 4. Adanya Rumah Tangga Perikanan & 4.40 & 3 & 0.13 \\
\hline 5. Legislasi dan regulasi perikanan dan kelautan & 5.49 & 3 & 0.16 \\
\hline 6. Lingkungan SDI yang relatif belum tercemar & 5.49 & 2 & 0.11 \\
\hline 7. Adanya Kawasan Lindung dan Konservasi & 5.49 & 2 & 0.11 \\
\hline \multicolumn{4}{|l|}{ WEAKNESSES (W)/ KELEMAHAN } \\
\hline 1. Pengembangan perikanan belum optimal dan terpadu & 7.69 & 4 & 0.31 \\
\hline 2. rendahnya sarana dan prasarana perikanan & 5.49 & 3 & 0.16 \\
\hline 3. Rendahnya kuantitas dan kualitas SDM & 10.99 & 3 & 0.33 \\
\hline 4. Lemahnya kemitraan, koordinasi dan komunikasi antar lembaga & 7.69 & 2 & 0.15 \\
\hline 5. Rendahnya pengawasan dan penegakan hukum & 6.59 & 3 & 0.20 \\
\hline 6. Rendahnya Investasi, akses modal, dan terbatasnya APBD & 8.79 & 3 & 0.26 \\
\hline 7. Rendahnya pemasaran dan akses pasar & 4.40 & 2 & 0.09 \\
\hline Total skor faktor kekuatan - kelemahan & & & 0.23 \\
\hline \multicolumn{4}{|l|}{ OPPORTUNITIES (O)/ PELUANG } \\
\hline 1. Adanya program kegiatan perikanan pusat & 6.67 & 4 & 0.27 \\
\hline 2. Berkembangnya paradigma nasional tentang budidaya perikanan & 11.11 & 2 & 0.22 \\
\hline 3. Adanya peningkatan pendidikan masyarakat & 6.67 & 2 & 0.13 \\
\hline 4. J umlah penduduk Indonesia yang besar & 1.11 & 1 & 0.01 \\
\hline 5. Adanya perkembangan teknologi perikanan & 8.89 & 3 & 0.27 \\
\hline 6. Berkembangnya paradigma tentang konservasi & 10.00 & 2 & 0.20 \\
\hline 7. Tingginya potensi pasar nasional dan internasional & 5.56 & 2 & 0.11 \\
\hline \multicolumn{4}{|l|}{ THREATS (T)/ ANCAMAN } \\
\hline 1. Illegal fishing dan illegal logging & 13.33 & 5 & 0.67 \\
\hline 2. Adanya fenomena penurunan populasi ikan di laut & 5.56 & 2 & 0.11 \\
\hline 3. Degradasi lingkungan SDI & 8.89 & 3 & 0.27 \\
\hline 4. Adanya fenomena Pemanasan Global & 2.22 & 2 & 0.04 \\
\hline 5. Tingginya potensi bencana alam & 2.22 & 2 & 0.04 \\
\hline 6. Adanya konflik kepentingan pemanfaatan SDA & 13.33 & 2 & 0.27 \\
\hline 7. Terbatasnya pasokan energi & 4.44 & 3 & 0.13 \\
\hline Total skor faktor peluang - ancaman & & & -0.32 \\
\hline
\end{tabular}




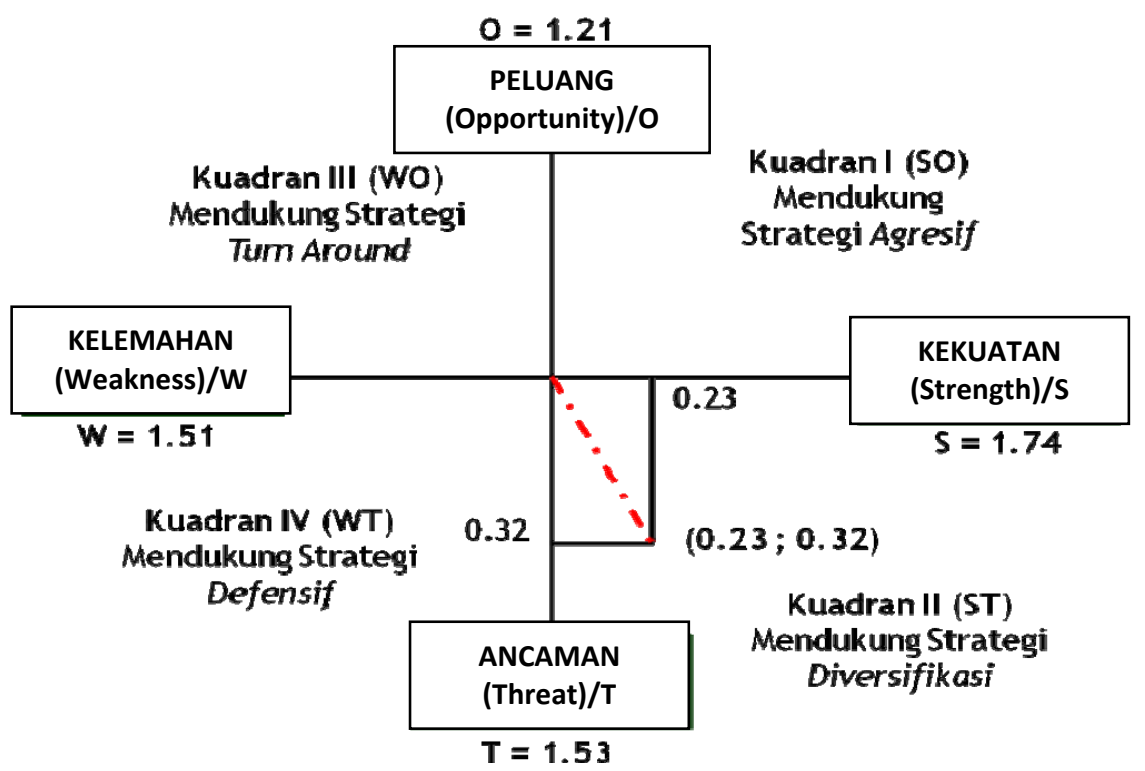

Gambar 1. Kuadran Strategi Pengelolaan Perikanan di Wilayah Pesisir Kabupaten Lampung Barat

Tabel 4. Strategi Pengelolaan Perikanan Wilayah Pesisir

\begin{tabular}{|c|c|c|c|c|c|c|c|c|c|}
\hline \multirow{2}{*}{\multicolumn{3}{|c|}{ STRATEGI }} & \multicolumn{5}{|c|}{ KETERKAITAN } & \multirow{2}{*}{ Skor } & \multirow{2}{*}{ Ranking } \\
\hline & & & $a$ & b & $\mathbf{C}$ & d & e & & \\
\hline \multicolumn{10}{|c|}{ STRATEGI (S-T) } \\
\hline ST 1 & \multicolumn{2}{|c|}{ Pengembangan budidaya perikanan (air tawar dan payau) } & 3 & 4 & 4 & 2 & 4 & 17 & 1 \\
\hline ST2 & \multicolumn{2}{|c|}{$\begin{array}{l}\text { Meningkatkan peran kelembagaan formal dan non formal } \\
\text { dalam menerapkan usaha yang ramah lingkungan dan } \\
\text { penanggulangan degradasi lingkungan }\end{array}$} & 3 & 3 & 2 & 2 & 2 & 12 & 3 \\
\hline ST3 & \multicolumn{2}{|c|}{$\begin{array}{l}\text { Menyelesaikan konflik kepentingan dalam pemanfaatan } \\
\text { SDA }\end{array}$} & 2 & 3 & 3 & 2 & 3 & 13 & 2 \\
\hline \multicolumn{2}{|c|}{$\begin{array}{l}\text { Keterangan } \\
\mathrm{a}=\text { Sumber daya manusia } \\
\mathrm{b}=\text { Metode } \\
\mathrm{c}=\text { Sarana dan prasarana }\end{array}$} & $\begin{array}{l}\text { Nilai } \\
1 \text { = Sangat rendah } \\
2 \text { = Rendah } \\
3 \text { = Cukup tinggi }\end{array}$ & \multicolumn{2}{|c|}{$\begin{array}{l}\text { Keterangan } \\
\mathrm{d}=\text { Dana } \\
\mathrm{e}=\text { Organisasi }\end{array}$} & \multicolumn{4}{|c|}{$\begin{array}{l}\text { Nilai } \\
4=\text { Tinggi } \\
5 \text { = Sangat tinggi }\end{array}$} & \\
\hline
\end{tabular}

Strategi ST2 dapat diimplementasikan dengan progam atau kegiatan; peningkatan pengawasan dan penegakan hukum, kajian biofisik dan lebar sempadan pantai di wilayah pesisir, penetapan peraturan daerah tentang sempadan pantai/sungai dan jalur penangkapan ikan. Sementara itu arahan strategi ST3 dapat diimplementasikan melalui program dan kegiatan; pembentukan Forum Mitra Bahari di Kabupaten Lampung Barat, serta peningkatan kemampuan aparatur dan fasilitas kelembagaan yang terkait.

\section{KESIMPULAN}

Wilayah pesisir Kabupaten Lampung Barat memiliki potensi sumberdaya perikanan yang besar dan beragam sebagai modal berharga bagi pengembangan perikanan dan pencapaian ketahanan pangan, namun demikian pe- ngelolaannya belum optimal dan berkelanjutan yang ditandai antara lain: tingkat pemanfaatan potensi perikanan tangkap di laut baru mencapai $55.7 \%$ dari potensi lestarinya, masih adanya aktivitas illegal fishing, serta belum berkembangnya kegiatan perikanan budidaya dan pengolahan ikan di wilayah pesisir. Kerusakan lingkungan dan menurunnya kualitas habitat sumber daya ikan yang masih berlangsung seperti abrasi pantai serta rusaknya ekosistem terumbu karang dan vegetasi pantai turut menjadi bukti belum lestarinya pengelolaan perikanan yang dilakukan.

Pada tahun 2007, produksi perikanan yang berasal dari wilayah pesisir memberikan kontribusi sebesar $90.78 \%$ dari total produksi perikanan di Kabupaten Lampung Barat. Seluruh produksi perikanan di Kabupaten Lampung Barat tersebut memiliki potensi penyediaan protein ikan untuk di konsumsi penduduk 
sebesar $7.66 \mathrm{gr} /$ kapita/tahun, atau 85\% dari jumlah protein ikan yang dianjurkan dikonsumsi (9 gr/ kap/ hari, WNPG, 2004). Untuk itu, dalam rangka pengelolaan perikanan yang optimal dan berkelanjutan dan pemenuhan kebutuhan protein ikan bagi masyarakat diperlukan strategi yang tepat. Berdasarkan hasil analisis SWOT posisi pengelolaan perikanan di pesisir Lampung Barat ada pada kuadran ke II yang berarti mendukung dilakukannya strategi diversifikasi yaitu strategi yang memanfaatkan kekuatan untuk menghadapi ancaman. Strategi tersebut dapat dijabarkan menjadi 3 (tiga) arahan strategi berdasarkan prioritasnya yaitu: Prioritas-1) Pengembangan budidaya perikanan air tawar dan payau (ST1), Prioritas-2) Menyelesaikan konflik kepentingan dalam pemanfaatan SDA (ST3), Prioritas-3) Meningkatkan peran kelembagaan formal dan non formal dalam menerapkan usaha yang ramah lingkungan dan penanggulangan degradasi lingkungan (ST2). Untuk mengimplementasikan arahan strategi tersebut di atas maka disusunlah rencana aksi dalam bentuk program dan kegiatan.

\section{DAFTAR PUSTAKA}

Dahuri R. 2008. Pendayagunaan Sumber Daya Kelautan Kesejahteraan untuk Rakyat
(Kumpulan Pemikiran Dr. Ir. Rokhmin Dahuri, MS). LISPI, J akarta.

[Diskanla] Dinas Perikanan dan Kelautan. 2006. Laporan Tahunan Statistik Perikanan Tangkap Kabupaten Lampung Barat Tahun 2006. Dinas Perikanan dan Kelautan Lampung Barat, Liwa.

[DKP] Departemen Kelautan dan Perikanan. 2008. Konsumsi Ikan Nasional Terus Meningkat. Situs Departemen Kelautan dan Perikanan Republik Indonesia. 2008. www.dkp.gov.id. [10 Nopember 2008]

Karyadi, Susilowati, \& Sudirman H. 1993. Potensi Gizi Hasil Laut untuk Menghadapi Masalah Gizi Ganda. Risalah Widyakarya Pangan dan Gizi. LIPI, J akarta.

Marimin. 2004. Teknik dan Aplikasi; Pengambilan Keputusan Kriteria Majemuk. Grasindo, J akarta.

Rangkuti. 2006. Analisis SWOT Teknik Membedah Kasus Bisnis-Reorientasi konsep perencanaan strategis untuk menghadapai abad 21. Gramedia Pustaka Utama, J akarta. 